\title{
A Distanced Eucharist in Bits and Bytes \\ Creating a True Encounter in Online Celebrations of the Mass during the COVID-19 Crisis
}

Michael-Dominique Magielse OP

\section{Abstract}

Since the beginning of 2020, liturgical life in many countries around the globe has changed due to COVID-19 lockdowns or other measures related to the worldwide pandemic. While churches had to close their doors to the faithful, or only allow a limited of people to attend mass, communities brought their Eucharistic celebrations online in livestreamed or Zoom services. This phenomenon has raised questions about the authenticity of online celebrations of the Eucharist. Can those online services be considered as 'real' liturgy? In this article, I will address this question by focusing on embodiment and presence in the liturgy and how these key concepts of liturgical studies are being established in a new existential context of the online realm.

\section{Keywords}

Eucharist, lockdown liturgy, encounter, pandemic, presence

\section{Introduction}

The COVID-19 pandemic has affected liturgical life dramatically in locked-down countries around the world. From March 2020 onward, many churches and other places of worship were closed, and people had to move for prayer and worship to the digital realm where online spirituality and livestreamed services were flourishing. A whole range of new possibilities and examples of 'lockdown liturgies' emerged on the internet and social media platforms. ${ }^{1}$ Livestreamed services have been dominating the digital liturgical landscape ever since.

Since the beginning of the summer, in many European countries churches gradually reopened their doors to allow a limited amount of people to attend services of worship, as long as they observed strict social distancing rules and other measures to avoid spreading the coronavirus. ${ }^{2}$ However, the

1) Cf. Heidi A. Campbell, ed., The Distanced Church: Reflections on Doing Church Online (Austin, TX: Digital Religion Publications, 2020).

2) Cf. RKKKerk.nl, “Nieuwe versie protocol ‘Kerkelijk leven op anderhalve meter' nu beschikbaar," accessed January 24, 2021, https://www.rkkerk.nl/nieuwe-versie-van-protocol-kerkelijk-leven-op-anderhalvemeter-nu-beschikbaar/\#more-10123. 
amount of online worship services available is still enormous. Some people prefer continuing to participate in digital liturgy as an expression of the 'new normal', while others are glad to be able to return to church buildings to participate in worship services and meet other members of the congregation. ${ }^{3}$

Along with a flourishing digital spiritual and liturgical life, discussions and questions arose about the validity of online liturgy and to what extent digitally mediated liturgical activities are 'real', especially when this concerns a livestream of the Eucharist or other sacramental celebrations. These questions are not new, neither are (online) broadcasts of liturgical celebrations. ${ }^{4}$ They existed long before the current pandemic. Since the 1960s, masses and other services of worship were being broadcast on TV, which made liturgists and other theologians ponder the theological implications of liturgical concepts such as participation, presence, and community. These discussions continued with the advent of the internet in the early 1990s, when people started spiritual 'experiments' with bringing religion online. We have learned a lot from these experiments, often through multidisciplinary discussions, in which media and ritual scholars also made important contributions. ${ }^{5}$

The outcome of these discussions can be helpful in finding or redefining an answer to the question of the extent to which digital liturgy is 'real'. ${ }^{6}$ Of course, answering this will always depend on normative sacramental theology of a particular church: in other words, it will be defined denominationally. The approach I take in reflecting on these questions will be from a Roman Catholic perspective, the following of which some would like to define as "a hard line when it comes to broadcasting sacramental events."7 In the document The Church and the Internet published by the Vatican in 2002, the Roman Catholic Church's view on sacramental life on the internet seems clear: "There are no sacraments on the internet; and even the religious experiences possible there by the grace of God are insufficient apart from real-world interaction with other persons of faith." 8 This means that participation in liturgy needs to take place in person, face-to-face, and that a broadcast or a livestream of, e.g., the Eucharist does not replace a celebration in which people are present together in a church building.

3) “Studie: Online-Gottesdienste auch nach Corona-Lockdown stark gefragt," accessed January 24, 2021, https://www.katholisch.de/artikel/26923-studie-online-gottesdienste-auch-nach-corona-lockdown-starkgefragt.

4)Teresa Berger, @Worship: Liturgical Practices in Digital Worlds (New York: Routledge, 2018).

5) Cf. Tim Hutchings, Creating Church Online: Ritual, Community and New Media (New York: Routledge, 2017).

6) With 'real' I ask whether it can be regarded as liturgy that is occurring in fact - not as an imitation or artificial but rather genuine and authentic by people participating in it and by theologians and the Church.

7) Daniella Zsupan-Jerome, "Is it Real? Mystagogizing the Livestream Service," in The Distanced Church: Reflections on Doing Church Online, ed. Heidi A. Campbell (Austin, TX: Digital Religion Publications, 2020), 91-93.

8) Pontifical Council for Social Communications (PCSC), The Church and the Internet (February 22, 2002), accessed August 26, 2020, http://www.vatican.va/roman_curia/pontifical_councils/pccs/documents/rc_pc_ pccs_doc_20020228_church-internet_en.html. 
However, things are never as black and white as they may seem. In reflecting on digital culture and online religion, the Catholic Church gradually has taken a more positive approach than was the case in 2002. ${ }^{9}$ This might open new possibilities in thinking about online sacramental life, without, of course, ignoring the theological boundaries set by digital liturgy.

\section{Liturgy as encounter}

Liturgy can be defined as a celebration of the paschal mystery and an encounter with God. It is a "personal meeting, under the veil of holy signs, of God with his Church and with the total person of each one of her members, in and through Christ and in the unity with the Holy Spirit." ${ }^{10}$ This encounter takes place in a double movement in the liturgy, in a descending and an ascending line: in God's sanctification of human beings and, in response, the glorification of God in worship as an "act of mankind"."11

Liturgy is encounter and action. It is first of all an action of God. It is opus Dei, his work, and secondly the work of the faithful, the Church, who enter into dialogue with God. People taking part in the liturgy address God, and they make statements about their belief in him with words they speak and sing, in rituals, manufactured objects and architecture, and in gestures and action. ${ }^{12}$ Liturgy is an action of the whole person, body and soul, in words and deeds.

This liturgical action is multiform. It is worship with and through the body. Entering the liturgy means a bodily experience of the ritual: "with mind and heart, with its imagination and memory, with the appreciation of beauty and with all its senses: eyes, ears, touch, smell and taste." ${ }^{13}$ Liturgy is about experience, not about explanation; its goal is not to produce meaning, but meeting, especially meeting God. ${ }^{14}$ As Romano Guardini has it, "the liturgy is not being brought alive by teaching, but mainly by doing it. ... Doing is elementary." 15 The question I will consider in this article is "How can you "do

9) This occurs particularly in the statements of various popes for World Communications Day. These statements are published each year on January 24. These messages, e.g., of pope Francis, can be found on the website of the Vatican: http://www.vatican.va/content/francesco/en/messages/communications.index. html\#messages.

10) Ambrosius Verheul, Introduction to the Liturgy: Towards a Theology of Worship (Wheathampstead: Anthony Clarke Books, 1972), 19.

11) Cf. Verheul, Introduction, 17-19.

12) Kevin W. Irwin, Context and Text: A Method for Liturgical Theology, rev. ed. (Collegeville: Liturgical Press, 2018), 70.

13) G. Danneels, "Binnentreden in de liturgie?" Pastoralia (1995): 5-6. Cited in Joris Polfliet, "Liturgie als ritueel handelen," Tijdschrift voor Liturgie 100 (2016): 28-29.

14) Nicholas Wolterstorff, Acting Liturgically: Philosophical Reflections on Religious Practice (Oxford: Oxford University Press, 2018), 84; Nathan Mitchell, Meeting Mystery: Liturgy, Worship, Sacraments (Maryknoll, NY: Orbis Books, 2006), 59.

15) Romano Guardini, Van heilige symbolen: Een inleiding in de levende werkelijkheid van de liturgie (Heemstede: Uitgeverij de Toorts, 1941). 
liturgy' in the digital realm? Or, more specifically, how is a real liturgical encounter established?" I will do so by examining two key concepts from the study of liturgy: embodiment and presence. ${ }^{16}$

\section{Virtual bodies and digital presence}

The 'reality' or authenticity of experiences of online worship is being contested because of the claim that a physical body and real presence are lacking. ${ }^{17}$ Both concepts are fundamental for liturgical participation. Critics say that digital liturgy is disembodied, because there is no physical bodily presence; digitally mediated practices are therefore 'deeply deficient'. ${ }^{18}$ Craig Baron, for example, argues that online rituals "do further a disembodied, non-communitarian, and ahistorical sense of sacramental participation." "19 A digital environment is virtual and therefore unreal. ${ }^{20}$

Since the dawn of the internet, Christians have adopted digital media for a variety of religious purposes, and online presence has become a vital means to connect to believers and spiritual seekers in a digital culture. The COVID-19 crisis has provided us with a striking example in which the internet as a network has empowered individuals and encouraged new forms of liturgical interaction, which could be described as forms of 'networked religion'. ${ }^{21}$

The idea of networked religion suggests that religion, which is found online and offline, is informed by the structures, practices and character of network society. Networked religion is defined by five key traits: networked community, storied identities, convergent practices, shifting authority, and a multisite reality. ${ }^{22}$

16) Digital liturgy does not only affect concepts such as embodiment and presence, but also participation, time and pace, and community, all of which are key concepts in the field of liturgical studies. During the COVID-19 pandemic, online and hybrid church communities were created in which people participated online or in a church. This phenomenon has ecclesiological consequences, of course: who is the ecclesia orans online or in a hybrid community? However, answering this question is beyond the scope of this contribution.

17) Real presence can either mean the physical presence of people participating in a liturgical event or the concept of Christ being present in liturgical events, e.g., in the species of bread and wine in Eucharistic celebrations.

18) Berger, @Worship, 18.

19) Craig Baron, “Sacraments ‘Really Save' in Disneyland: Reconciling Bodies in Virtual Reality," Questiones Liturgiques 86 (2005): 305.

20) Virtual here refers to a simulated reality created, e.g., through software. The question is whether people who are participating in online liturgical events are being present with a virtual or with their physical body. I will address this question further on. Cf. Nick Couldry and Andreas Hepp, The Mediated Construction of Reality (Cambridge: Polity Press, 2017), 51.

21) Heidi Campbell and Stephen Garner, Networked Theology: Negotiating Failth in Digital Culture (Grand Rapids, MI: Baker Academic, 2016), 64.

22) Campbell and Garner, Networked Theology, 64. 
In everyday life the online-offline distinction has blurred, since the internet has become embedded in everyday realities, including our spiritual or religious life. Heidi Campbell captures this with the term 'digital religion', which describes how the internet has become an integrating force that bridges and extends online religious practices and offline religious activity, e.g., liturgical practices in church buildings. Digital religion "describes the technological and culture space that is evoked when we talk about how online and religious spheres have blended." 23 This has made the internet a place of worship where liturgical practices occur that are digitally (technically) mediated, which I define as 'digital liturgy', a term that I argue is interchangeable with online liturgy, which refers to the opportunity for participating in liturgical activity online. ${ }^{24}$

The internet has become a multisite reality in which we distinguish various elements of online and offline culture blended in a unique context, one reality, one environment, that must be considered a new actuality. ${ }^{25}$ This new actuality is a 'real space', which has been organically integrated in our everyday lives; it is a new existential context. ${ }^{26}$ In other words, the digital realm is a real, authentic space and, consequently, liturgical practices in this real space are real as well. In her book @Worship, liturgical scholar Teresa Berger calls upon liturgists to engage openly with digital liturgical practices and to recognize that key concepts in the study of liturgy, such as embodiment and presence, might change. $^{27}$

What the COVID-19 crisis has demonstrated is that this new existential context has proved its value as a place where people could follow livestreamed services, gather in liturgical Zoom-meetings and liturgies, watch video-messages from religious leaders, etc. ${ }^{28}$ The church has never been as present and visible on the internet as in the last year. This lowered barriers for people to participate in livestream services and other practices of worship online. I argue that it therefore provided an enormous opportunity for people to see what Christians are about. Online churches do not only reach out to people; their digital presence is also an act of public witness of faith. ${ }^{29}$ It enabled the creation of an environment for true encounter, which means an authentic encounter in the experience of the people involved.

Within the Catholic Church, there is a growing recognition of digital true encounter. In 2013, Pope Benedict XVI stopped referring to the digital environment as a parallel or purely virtual world,

23) Heidi Campbell, "Introduction," in Digital Religion: Understanding Religious Practice in New Media Worlds, ed. Heidi Campbell (New York: Routledge, 2013), 3-4.

24) Cf. Christopher Helland, "Online Religion as Lived Religion. Methodological Issues in the Study of Religious Participation on the Internet," Online - Heidelberg Journal of Religions on the Interent 1 (2005).

25) Campbell and Garner, Networked Theology, 73-77.

26) Antonio Spadaro, Friending God: Social Media, Spirituality and Community (New York: The Crossroad Publishing Company, 2016), 23.

27) Berger, @Worship, 5.

28) “Studie: Online-Gottesdienste auch nach Corona-Lockdown stark gefragt."

29) Zsupan-Jerome, "Is it Real?" 91. 
but as being a part of the experience of people's daily lives. Media do not merely function for sharing information, but function in sharing our lives, our selves. "The growing dialogue in social networks about faith and belief confirms the importance and relevance of religion in public debate and in the life of society." 30 Benedict refers to the importance of social media because they have the potential to foster human and religious development. They create a new agora (marketplace) where people not only share information, images, ideas and opinions, but where new relationships and forms of community can also arise:

In the digital world there are social networks which offer our contemporaries opportunities for prayer, meditation and sharing the word of God. But these networks can also open the door to other dimensions of faith. Many people are actually discovering, precisely thanks to a contact initially made online, the importance of direct encounters, experiences of community and even pilgrimage, elements which are always important in the journey of faith. ${ }^{31}$

Acknowledging real spiritual experiences online is one thing; however, the 'reality' of online liturgical experiences is still being contested. One of the recurring objections to the authenticity of these experiences is that they lack a physical body or embodiment..$^{32}$ Teresa Berger responds to this objection by arguing that "no digital world can be entered, no website accessed, and no app installed without a body." 33 Moreover, there is always someone at a keyboard behind a computer, touching the screen and staring at it, undergoing a physical experience through the senses, thus the body. ${ }^{34}$ Praying and being at worship in the digital space is simply not possible as a disembodied activity. An example is the invitation when using the Pray-as-You-Go app for a daily guided mediation. The meditation starts with breathing and body exercises, which someone would not find before a service in a church building. Without the actual body, worship either in a church or in the online realm is not possible. However, online bodily presence does not exactly follow the traditional lines of the presence of the body in worship. 35

This shows, according to Berger, that the claim of critics that "digital liturgy happens without the requirement of a physical body present" is far too unsubtle. She argues that multi-medial environ-

30) Benedict XVI, "Message for World Communications Day: Social Networks: portals of truth and faith; new spaces for evangelization. May 12, 2013," accessed August 26, 2020, http://www.vatican.va/content/benedictxvi/en/messages/communications/documents/hf_ben-xvi_mes_20130124_47th-world-communications-day. html.

31) Benedict XVI, "Social Networks."

32) Berger, @Worship, 18.

33) Berger, @Worship, 18.

34) Ronald Grimes, Deeply into the Bone: Re-inventing Rites of Passage (Berkeley: University of California Press, 2000), 273.

35) Berger, @Worship, 18. 
ments often are multi-sensory and therefore have a bodily effect on participants; this "may at times be greater than in a typical Sunday worship service." 36 Peter Horsfield takes it one step further:

Digital technologies address the aural, oral, tactile, visual, and kinetic functions of the body in ways that are reworking the relationship between reason, imagination, and the emotional in the evaluation and integration of information, experience, and perception. ${ }^{37}$

There is always a physically present body to enter in online worship. "Digitally mediated practices of prayer and worship cannot be separated from a physical body." 38 Thus, rather than claiming that online liturgy is fundamentally disembodied, "digitally mediated worship entails its own specific bodily proprieties", but always in a continuum with offline bodily presence at worship. ${ }^{39}$ Many online liturgical practices are rooted in offline activities. For example, an online devotional activity can start by making the sign of the cross. Digital liturgy often is a supplement to offline church involvement or, in times of the COVID-19 pandemic, a temporary replacement.

This does not mean there are no boundaries of bodily action in digital liturgy. Despite advanced technologies, it is still not possible to feel the warmth of burning candles, smell the incense, and feel the holy water when entering a sacred space; nor is it possible to share bread and wine. The sensory experience in digitally mediated liturgical activities is to a certain degree (still) limited: not everything can be digitally mediated.

The concept of the body and embodiment in the liturgy is deeply connected with the notion of being present. This presence is complex, not only in digital culture, but in the whole liturgical tradition of Christian worship. In the very early Church, Justin Martyr (c. 100-165) wrote in his Apology about the Eucharist and described a Eucharistic gathering of his community. ${ }^{40} \mathrm{He}$ insists that deacons bring communion to those who are absent, the sick and others. This example demonstrates that the ecclesial community and sharing in the Eucharistic were not restricted to those who were physically present. ${ }^{41}$ Although they were not bodily present, they belonged to a particular celebration. ${ }^{42}$

Another example can be found in the writings of Peter Damian (c. 1007-1072), who reflects in his treatise Liber qui dicitur Dominus vobiscum (The book of The Lord be with You) on the rise of private masses of hermits. His question was whether a hermit, when praying the Office of the Hours or cel-

36) Berger, @Worship, 19.

37) Peter G. Horsfield, From Jesus to the Internet: A History of Christianity and Media (Chichester: Wiley

Blackwell, 2015), 265.

38) Berger, @Worship, 19.

39) Berger, @Worship, 20.

40) Justin Martyr, Apology I, 65.

41) Berger, @Worship, 24.

42) Teresa Berger, “@Worship. Exploring Liturgical Practices in Cyberspace,” Questions Liturgiques 94 (2013): 277 . 
ebrating a mass in solitude, could use the plural in the prescribed liturgical texts such as Dominus vobiscum. Would a hermit in this case not merely be speaking to the walls of his cell? Peter Damian insists that a hermit should use the plural because it is not the individual hermit who celebrates the liturgy, but the whole Church in the Holy Spirit, which is present in every liturgy: there is, therefore, always a broader ecclesial belonging. According to Peter Damian, it is not the number of people visibly present that determines who is in attendance in the liturgy, but the presence of the Body of Christ, the mystery of the whole Church. ${ }^{43}$

These words show that the sacrifice of praise is offered by all the faithful, not only by men but also by women, even though it might appear to be offered in a special way by the priest alone.... If then we are the one body of Christ and if, while appearing to be separate in physical appearance, we are unable to be separated from one another because of the Spirit (we who live one same life in him), what is wrong (I myself see nothing wrong) in our being united as faithful in the church's communal action even when we are physically separated? 44

Peter Damian stresses the presence of the whole Church in every liturgy. From the experience of the hermit he summarizes his argument:

Let therefore the hermit in his cell not fear to pray those words that refer to the communion of the whole church, because he is indeed joined with all, in the unity of the one faith in love, even when physical space distances him from the gathering of the faithful. ${ }^{45}$

Peter Damian, among others, points out that one never prays the prayer of the Church alone. Peter Damian's notion could nowadays be applied to the reality of digital culture and digital liturgical celebrations. In the current liturgy of the Roman Catholic mass, when praying or hearing the Eucharistic prayer, a clear example of the ecclesial communio beyond physical co-presence is given. I refer to the communion of saints embodied in the Eucharistic prayer. We mention saints, but also the pope and the local bishop, representing the universal and local Church as being part of the ecclesial communion being performed while praying, without them being physically present. ${ }^{46}$ We can also think of the members of a community that are too ill or too old to join the community in church but are yet included in the celebrating community or the people of the community that are being remembered in our prayers, the living and the dead. ${ }^{47}$
43) Berger, @Worship, 24.
44) Petrus Damiani, Liber qui dicitur Dominus vobiscum, VIII. (The English translation is taken from Yves Congar, "The Ecclesia or Christian Community as a Whole Celebrates the Liturgy," in At the Heart of Christian Worship: Liturgical Essays of Yves Congar, ed. Paul Philibert (Collegeville: Liturgical Press, 2010), 26-27.
45) Damiani, Liber qui dicitur Dominus vobiscum.
46) Cf. Berger, “@Worship” (2013), 277.
47) Willem Marie Speelman, “The Celebration of the Body," Questiones Liturgiques 87 (2006): 200. 
What these examples and the liturgical tradition in general demonstrate is that digital liturgy does not entail a radical revolution: on the contrary, it represents transformation and reconfiguration of existing practices. ${ }^{48}$ How can this help in exploring the liturgical concept of online presence? First of all, the liturgical tradition shows us that the concept of presence in the liturgy is obvious, but not restricted to a liturgical gathering and, secondly, that that 'virtual' presence is as old as Christian worship itself. It is complex, and digital culture contributes to this complexity.

Liturgical presence is established by our body being present in a specific location at a certain time. ${ }^{49}$ When using social media, we are able to extend our bodily presence by using texts, geo-tags, photos, and videos across space and time. Characteristic of social media is that they are highly participatory and that there is interaction. We can press 'like' buttons and share comments while attending a livestreamed celebration on YouTube or Facebook. It is in the interaction that the digital presence is experienced, which makes it a relational presence. Daniella Zsupan-Jerome argues that "gathering as a community in the flesh is often enhanced and enriched by such digitally mediated presences." The Catholic Church recognized this during the World Youth Day of 2013 in Brazil. Pope Francis had announced a plenary indulgence to anyone prayerfully participating in the World Youth Day events, whether they were physically present in Brazil, watching TV or listening to the radio, or by "means of social communication". 50

We easily add to this the example of the many initiatives by priests and communities around the globe in providing livestream masses and other worship services during the COVID-19 pandemic. If we follow the conventional lines of liturgical scholarship regarding presence and physical co-presence in the liturgy, we might encounter a problem here. The point is that online presence does not exactly follow these lines. ${ }^{51}$ We communicate through words and images on social media platforms like Zoom, Facebook, and YouTube. This constitutes a presence in substance, not in physicality. ${ }^{52}$ The digital media have reinforced the fact that we can be substantially but not physically present to one another..$^{53}$

Using a term such as substantial presence resonates with how Christ's presence is understood in the Eucharist: substantial, not physical. The way people encounter Christ in the liturgy is multi-layered; it is a mediated presence. People do not meet him face-to-face, but Christ is met in real presence in the Eucharistic elements, in his presence in the word, the presider, and the faithful assembled. ${ }^{54}$ This

\footnotetext{
48) Berger, @Worship, 16.

49) Daniella Zsupan-Jerome, "Virtual Presence as Real Presence? Sacramental Theology and Digital Culture in Dialogue," Worship 89 (2015): 526.

50) Zsupan-Jerome, “Virtual Presence," 527; http://www.vatican.va/roman_curia/tribunals/apost_penit/ documents/rc_trib_appen_doc_20130709_decreto-indulgenze-gmg_en.html; last accessed August 28, 2020.

51) Berger, @Worship, 18.

52) Zsupan-Jerome, "Virtual Presence," 527.

53) Zsupan-Jerome, "Virtual Presence," 527.

54) SC 7.
} 
makes the Eucharistic encounter a mediated encounter. Christ is personally absent, but his presence in constituted through mediation.

This approach creates possibilities for new theological reflections on mediated presence in digital liturgy, such as livestreamed masses. Zsupan-Jerome acknowledges that the multilayered understanding of presence in the Eucharistic liturgy is complex. Yet, she argues, "this complexity makes room for exploring how the digital medium may convey authentically presence, if not physically then substantially." 55 She understands Eucharistic presence as fundamentally relational, "which provides a solid theological basis, source and summit for authentic culture of encounter possible in the digital age." 56

In the doctrine of the transubstantiation, the Roman Catholic Church provides a classical Aristotelian metaphysical lens to explore the real presence of Christ in the Eucharist in the 'species' of bread and wine: in other words, Christ's presence in substance through the accidents of bread and wine. Applying this to the digital realm, I argue that people online are present in substance through texts in comments during a livestreamed mass on YouTube or Facebook, in Zoom-sessions, and in photos and videos. It is, for example, quite common nowadays to say, 'I met Peter yesterday', referring to an online Skype conversation with him the day before, or 'I attended mass yesterday', meaning that you participated in a livestreamed celebration.

We could add to this metaphysical lens a more phenomenological approach. This can make room for seeing the Eucharistic presence as fundamentally relational, as a presence for us: "the contextual, relational reality of Christ being there, not only objectively, but subjectively a being there for us." 57 By using a phenomenological interpretive lens on the concept of presence, the focus of Christ's Eucharistic presence shifts from being present in the Eucharistic species - which remains paramount in the Church's teaching - to the liturgical community as a fundamental locus in which Christ's presence unfolds. Nathan Mitchell captures this as follows:

God's kenotic 'self' is always a going-out towards others, and God's 'place' is the opening of space for worship, doxology, praise. God's 'presence' in the liturgy is thereby revealed as a 'making room for others', as opening a hospitable 'doxological domain: where others may meet. Presence is, therefore, a relational category; it is always presence of, presence to, presence for, and hence it inevitably implies 'otherness'. ${ }^{58}$

A phenomenological interpretation does not invalidate the metaphysical approach; rather, it gives room for other modes of presence to emerge. ${ }^{59}$ Within the context of the liturgy itself, things, people,

55) Zsupan-Jerome, "Virtual Presence," 529.

56) Zsupan-Jerome, "Virtual Presence," 529-30.

57) Zsupan-Jerome, "Virtual Presence," 532. (Emphasis in orginal.)

58) Nathan Mitchell, "Present in the Sacraments," Worship 80 (2006): 350-51.

59) Zsupan-Jerome, "Virtual Presence," 533. 
symbols, and actions all become a way to encounter Christ. It is in these symbols of the liturgy that Christ's presence is revealed. This can be helpful in the dialogue of sacramental theology with digital culture and digital communications. The complex, symbolic system of Christ being present in liturgical symbols offers the possibility of thinking of online liturgical encounter as true encounter. In other words, "this complexity allows for the possibility of authentic mediated presence in communication, beyond just the fundamental physical modality of face-to-face." 60 Within the liturgy, the (sacramental) encounter with God is not face-to-face. Marie-Louis Chauvet reminds us that we meet Christ in his absence, which allows faith to emerge and grow. This makes faith "the most radical mediation of his absence." 61

The sacramental encounter of Christ's presence is a mediated encounter, similar to a digitally mediated encounter. But this does not mean that these encounters are 'disembodied'. On the contrary, the body is indispensable for a mediated encounter - "there is no disembodied sacramental presence." 62 The word, presider, community, and sacrament are the liturgical signifiers through which the encounter is mediated. Referring to the definition of liturgy I used above, these signifiers, or holy signs, may veil Christ's face, but the body encounters him: the physical body of the participating person (online or offline) and the ecclesial body of worship. Offline face-to-face presence is important but not essential for true encounter and authentic communication. Authentic sacramental encounter is relational, face-to-face and mediated. ${ }^{63}$

\section{Reproduction}

Many livestreamed masses and worship services remain available on platforms such as YouTube and Facebook, enabling people to re-watch a liturgical event. Numerous papal liturgical celebrations are stored on the Vatican's YouTube channel, which has millions of views. A frequent objection is that liturgical presence in these celebrations is reduced to information that can be reproduced and replicated online. This raises the question whether online liturgy should be considered a genuine liturgical event or, rather, as a technological reproduction of that same event.

In The Church and the Internet (2002) cited above, the Vatican states that virtual reality cannot substitute for the real presence of Christ in the Eucharist and in other sacraments and worship. ${ }^{64}$ However, the same document leaves room for devotional digital liturgical practices by speaking of "religious experiences that are possible by the grace of God", even online. ${ }^{65}$ Antonio Spadaro links this to

60) Zsupan-Jerome, "Virtual Presence," 534.

61) Louis-Marie Chauvet, Symbol and Sacrament: A Sacramental Reinterpretation of Christian Existence (Collegeville: The Liturgical Press, 1995), 177.

62) Zsupan-Jerome, "Virtual Presence," 535.

63) Zsupan-Jerome, "Virtual Presence," 535.

64) The Church and the Internet, 9.

65) The Church and the Internet, 9. 
various forms of spiritual communion from within the Catholic tradition, such as those attested by the Council of Trent (1545-1563). ${ }^{66}$ However, he also has some objections concerning the here and now, hic et nunc, in liturgical celebrations. Spadaro explains that liturgical presence is bound to concrete events that take place here and now animated by the action of the Holy Spirit. ${ }^{67}$ In a digital context the "here and now' is contested, because virtual access would disconnect the person behind the screen from a 'physical' and 'geographical' presence that is required for the efficacy of the liturgical encounter. United States bishops consider digital liturgy merely as electronic projections that "seem to lack the capability to communicate at the level of the word, action and physical perception that are natural for those who are physically present." 68 These projections create a "limited presence", according to the American bishops.

On the other hand, people who are involved in digital liturgical activities have an identity in time and space. "The corporality of people with a name is the location of the experience to be I-herenow, an experience indivisibly connected with the real presence." ${ }^{69}$ This means that through the body "I have the awareness of here and now."70 Moreover, a continuing development of communication technologies has changed the possible conditions to overcome the 'here and now', and it is hard to keep pace with these developments. Digital communication cannot be reduced to just a static image or text: it is an extension of our sensibilities, which makes digital communication bodily. Spadaro acknowledges that many affective relationships are mediated by 'machines', such as computers and mobile devices. ${ }^{71}$

If reality cannot be reduced to information, it remains true that information permits some form of participation in the liturgical environment, which is undoubtedly more interactive and engaging than pure television viewing. ${ }^{72}$

An interesting example that responds to the objections mentioned above is an initiative of a number of Catholics in the Netherlands. To offer an alternative to livestreamed masses, they celebrate the Eucharist during a Zoom session called OnlineMis.nl. During the session on Sunday morning, a priest cel-

66) Antonio Spadaro, Cybertheology: Thinking Christianity in the Era of the Internet (New York: Fordham University Press, 2014), 75-76.

67) Zsupan-Jerome, "Virtual Presence," 529, 33; Cf. Spadaro, Cybertheology, 79.

68) Cited in Spadaro, Cybertheology, 79. Spadaro refers to a hyperlink of the US Conference of Catholic Bishops that no longer works (footnote 14, page 116).

69) Speelman, "Celebration of the Body," 200; Cf. Willem Marie Speelman, Liturgie in beeld: Over de identiteit van de rooms-katholieke liturgie in de elektronische media (Tilburg: Liturgisch Instituut, 2004), 128.

70) Willem Marie Speelman, "Hier is mijn lijf. Over onze lichamelijke aanwezigheid in de liturgie," Tijdschrift voor Liturgie 100 (2016): 46.

71) Spadaro, Cybertheology, 80.

72) Spadaro, Cybertheology, 80. 
ebrates mass in a chapel. The faithful join from their houses, some of them provide music, some read from Scripture, others provide bidding prayers, etc. Participation is encouraged by song and prayer texts provided through shared screens. People respond to the dialogues in the liturgy; they may kneel, stand, or make the sign of the cross. On a typical Sunday during the lockdown period in the Netherlands, this Zoom-mass had around seventy connections, behind which were three participants on average. They highly appreciated this initiative and called for maintaining the Zoom-mass even after the lockdown had ended. ${ }^{73}$ In this digital Eucharistic celebration, people are not merely spectators: they are present and participate bodily in a session in the here and now.

\section{Collective memory}

Much has been learned from TV-masses, which have been broadcasted since the beginning of the 1960s. At first, these masses were evaluated negatively, as they were regarded as "essentially passive and non-participatory". ${ }^{74}$ However, what the study of liturgy has gained from media studies on TV masses is that people watching the Eucharist on TV were not merely spectators, but, because of the relational aspect of the sacramental encounter, they became part of the liturgical event as real participants. These studies showed that people transformed from being viewers into recipients: they were not in the liturgical place itself, but they could put themselves into the liturgy with their whole personal being. ${ }^{75}$ These recipients are now understood to be actively engaged participants in the process of reception. ${ }^{76}$

This receptivity of the liturgy is being created and negotiated as long as people have the intentional disposition of wanting to be part of it. This notion did not emerge from recent media studies but has its roots within the tradition of the Catholic Church in what is described as 'spiritual communion'. This means that people can share in the effect of sacramental participation without actually being part of it. Thomas Aquinas wrote about spiritual communion for people who are in some way hindered from receiving the sacrament. According to Aquinas, it is possible that someone who is not physically present still can receive the effect of the sacrament "whereby a man is spiritually united with Christ through faith and charity."77 And in his encyclical letter Ecclesia de eucharistica, Pope John Paul II cites mystic Teresa of Avila (1515-82), who is rather clear on people who want to go to mass but cannot attend: "When you do not receive communion and you do not attend Mass, you can make a spiritual communion, which is a most beneficial practice; by it the love of God will be greatly impressed on

\footnotetext{
73) The initiative has stopped after the summer of 2020

74) Berger, @Worship, 22.

75) Speelman, Liturgie in beeld, 130-31.

76) Berger, @Worship, 22.

77) Thomas Aquinas, Summa Theologiae (Benzinger Bros), https://dhspriory.org/thomas/summa/index.html, 1947.III, 80,1.
} 
you." ${ }^{\prime 78}$ The desire to participate in a liturgical celebration creates an attentive presence of the faithful in their bodily existence, which constitutes a fully conscious and active participation in the liturgy. ${ }^{79}$

Another, and more recent, source that confirms the idea of spiritual communion is the letter Sacerdotium ministeriale, which cardinal Joseph Ratzinger, at the time prefect of the Congregation of the Doctrine of Faith, sent in 1983 to the Catholic bishops. In this letter Ratzinger states that through intentional participation - that is, through the desire to participate - people "no matter how distant they may be physically, are intimately and really united to her [the Church] and therefore they receive the fruits of the sacrament." 80 The idea of spiritual communion provides possibilities for reflecting on the efficacy of participation in digitally mediated liturgical activities. Many conferences of bishops around the world provided special prayer cards, which could be shown onscreen during livestreamed masses during the lockdown and by which people could make an act of spiritual communion. ${ }^{81}$

In various countries after a period of lockdown, the churches reopened their doors and people were able to rejoin their congregation for mass; however, in many places the supply of livestreamed services continued, and hybrid online-offline communities are being established. ${ }^{82}$ These communities are not created by the physical or online co-presence of worshippers, but rather by Christ who is the first actor in the liturgy. He assembles his body, the Church, not merely as a community in a certain place or time, but as a communio in which its members do not focus their attention on each other, but rather on God who is being praised and glorified. ${ }^{83}$ People do not create this communio, through their baptism and sharing in the Eucharist they are communio, Christ's own body, which goes beyond any local liturgical gathering. Participating in the liturgy creates an anamnestic effect, whether they participate online or offline: it is an expression of the community, the body of Christ, which they already are, and yet still have to become. ${ }^{84}$

The anamnesis as the liturgical commemoration of God's saving work consists of actions, or a ritual program, and memorial expressed in the narration of the saving works of God. ${ }^{85}$ When we apply

78) Teresa of Ávila, Camino de Perfección, chapter 35. Cited in John Paul II, Encyclical letter Ecclesia de eucharistica: On the Eucharist and its Relationship to the Church, April 17, 2003, 34.

79) Speelman, "Celebration of the Body," 203. Cf. SC 14.

80) Sacred Congregation for the Doctrine of Faith, Letter to Bishops of the Catholic Church on Certain Questions Concerning the Minister of the Eucharist (1983), accessed on August 21, 2020, http://www.vatican. va/roman_curia/congregations/cfaith/documents/rc_con_cfaith_doc_19830806_sacerdotium-ministeriale_ en.html.

81) An example of a prayer card for spiritual communion can be found on the website of the Catholic broadcasting network EWTN: https://www.ewtn.com/catholicism/devotions/act-of-spiritual-communion-339, accessed August 20, 2020.

82) "Studie: Online-Gottesdienste auch nach Corona-Lockdown stark gefragt."

83) Spadaro, Cybertheology, 74.

84) In a sermon (57) on the Eucharist St. Augustine writes about receiving the sacrament: "Behold what you are, become what you receive".

85) Daniel P. McCarthy, "A Gentle Light in Mourning. Fulfilling Christian initiation and Life at Funerals," Ecclesia Orans 36 (2019): 105-7. 
this to online liturgy, we must not interpret what we see on the screen as an imitation or a reproduction of a 'real' liturgical celebration elsewhere. We must rather see it as a demonstration and an invitation to follow what we see and hear in the narration of Christ's saving deeds in such a way that Christ can become present and that we are in communion with him and his church.

It is within the ritual program or action of anamnesis that through persons, symbols, and signs that Christ's presence is constituted. I argue that in digital liturgy we can consider being present with a receptive, faithful attitude as anamnestic action, in which the communio with Christ and his body is established and experienced as an authentic encounter; what we see and hear through digital mediation is the memorial of God's saving work. It is being done in such a way that the relational and mediated encounter is being established in the commemorative actual presence. ${ }^{86}$

In the liturgy, the assembled Body of Christ participates fully, consciously, and actively in the paschal mystery of Jesus Christ in glorifying God through the sanctification of men. ${ }^{87}$ It is what Bruce Morrill calls the Formal and Popular Anamnestic Model ${ }^{88}$ in which the liturgical rites of the Church, "the Spirit of the one who raised Jesus from the dead" (Rom 8:11) empowers believers through word and sacrament to know and to believe in what that Spirit anonymously is laboring to effect in their lives and that of the whole world." "If Christians practice ways of incarnating the paschal mystery through other prayer practices", argues Morrill, "all the more through moral and social-ethical practices, can the liturgical proclamation of God's glory and humanity's salvation have any verification." ${ }^{89}$ Morrill refers to Louis-Marie Chauvet, who argues that liturgy reveals an ethical program; a life of faith and love means that the grace we receive through the sacraments is a task we have to accomplish, that "we become, what we have received", the body of Christ. ${ }^{90}$

According to Chauvet, the sacrament gives ethics the power to become a 'spiritual sacrifice'; it is ethics that gives the sacrament the mean of 'verifying' its fruitfulness. ${ }^{91}$ We are reminded of and called upon to make this 'spiritual sacrifice' over and over again when we participate in the liturgy, whether this is in a church or online.

86) Albert Gerhards and Benedikt Kranemann, Introduction to the Study of Liturgy (Collegeville: Liturgical Press, 2017), 201. This is the case in hybrid forms of online-offline digitally mediated liturgies: however, I argue that this also counts for, e.g., watching a broadcast of a TV-Mass on demand.

87) SC 14.

88) Bruce Morrill, “Models of Liturgical Memory: Mystical-Political Dimensions, Mythic-Historic Tensions," Studia Liturgica 50, no. 1 (2020): 52.

89) Morrill, "Models of Liturgical Memory," 52-53.

90) Louis-Marie Chauvet, The Sacraments: The Word of God and the Mercy of the Body (Collegeville: The Liturgical Press, 2001), 65.

91) Chauvet, The Sacraments, 65. (Emphasis in orginal.) 


\section{Conclusion}

Since the COVID-19 lockdown period, online liturgical activities have been flourishing, particularly livestreamed masses and other worship services. These celebrations have created many good and meaningful experiences for numerous of people, and Christianity has never been as visible online as in the last year. However, the reality of these experiences is contested. The objections are not new. They emerged from the moment religion was brought online at the dawn of the internet. Many objections concern liturgical concepts such as body and presence. By referring to studies from the past, the liturgical tradition, and a phenomenological approach in sacramental theology, I tried to counter the objections by demonstrating that the liturgical concepts of body and real presence are not absent in online liturgy as some critics of digital liturgy might claim. These concepts change according to the conditions of digital culture. These conditions do not follow the traditional lines of liturgical study concerning presence and body in worship. These concepts transform, which asks for openness in engaging in these concepts in the 'new liturgical normal' of hybrid online and offline liturgies.

Michael-Dominique Magielse OP (MA/STL) is a Dominican Friar of the Dutch Province of the Order of Preachers. He is working on a PhD project on digitally mediated liturgical practices at the School of Catholic Theology of Tilburg University (NL).

Email: m.w.c.c.a.magielse@uvt.nl 